\title{
A Review of Climate Change Impacts on Agribusiness Value Chain in Nigeria
}

\author{
Toong Hai Sam ${ }^{1, *}$, Zainab Lawal Gwadabe ${ }^{1}$, Wong Chee Hoo ${ }^{1}$, Whee Yen Wong², \\ Tan Seng Teck ${ }^{1}$, Alex Hou Hong Ng$^{1}$, Asokan Vasudevan', Alvin Liau Chee How ${ }^{3}$ \\ ${ }^{1}$ Faculty of Business, Communications and Law, Inti International University, 71800 Nilai, Negeri Sembilan, Malaysia \\ ${ }^{2}$ Lee Kong Chian Faculty of Engineering \& Science, Universiti Tunku Abdul Rahman, Sungai Long Campus, Jalan Sungai Long, \\ Bandar Sungai Long, 43000 Kajang, Selangor, Malaysia \\ ${ }^{3}$ Faculty of Management, Deakin University, Melbourne Burwood Campus 221 Burwood Hwy, Burwood VIC 3125, Australia
}

Received March 1, 2021; Revised May 12, 2021; Accepted July 5, 2021

\section{Cite This Paper in the following Citation Styles}

(a): [1] Toong Hai Sam, Zainab Lawal Gwadabe, Wong Chee Hoo, Whee Yen Wong, Tan Seng Teck, Alex Hou Hong Ng, Asokan Vasudevan, Alvin Liau Chee How , "A Review of Climate Change Impacts on Agribusiness Value Chain in Nigeria," Universal Journal of Agricultural Research, Vol. 9, No. 4, pp. 119 - 126, 2021. DOI: 10.13189/ujar.2021.090403.

(b): Toong Hai Sam, Zainab Lawal Gwadabe, Wong Chee Hoo, Whee Yen Wong, Tan Seng Teck, Alex Hou Hong Ng, Asokan Vasudevan, Alvin Liau Chee How (2021). A Review of Climate Change Impacts on Agribusiness Value Chain in Nigeria. Universal Journal of Agricultural Research, 9(4), 119 - 126. DOI: 10.13189/ujar.2021.090403.

Copyright $\mathrm{C} 2021$ by authors, all rights reserved. Authors agree that this article remains permanently open access under the terms of the Creative Commons Attribution License 4.0 International License

\begin{abstract}
This paper aims to review the impact of climate change on Nigeria's agribusiness value chain. In this study, the researcher reviewed recent and popular academic journals in the area of climate change and agricultural value chains. This review process aims to strengthen the existing literature in this field of study. After carefully reviewing the literature, the paper revealed that the change in the global climate has a significant impact on the agribusiness value chain. The Nigerian agricultural value chain consists of the pre-upstream, up-stream, mid-stream, and down-stream. All the streams are directly or indirectly affected by climate change. The climate change impact varies across the value chain; it affects each stream with a different magnitude. The review also revealed that climate change has a significant effect on the food production value chain with a higher impact on pre-upstream and upstream when compared to mid and downstream. Suggestions presented in this paper include focusing on greenhouse gas reduction, practicing precision farming, using a reusable source of energy, taking advantage of IoT, and climate-smart agricultural technologies. This review will help the value chain stakeholders to understand how to achieve sustainability on the value chain and understand how to mitigate or adapt to climate change impacts.
\end{abstract}

Keywords Climate Change, Value-Chain,
Agribusiness, Nigeria

\section{Introduction}

Nigeria is a country located in the western part of Africa. The country is predominantly an agricultural nation. The majority of the population is in one way or the other engaged in the agribusiness value chain [1]. According to [2], in 2017, the agricultural sector contributed to $20.95 \%$ of the gross domestic product because the industry is one of the major sources of export, second after oil. Nigerian economy took a hit from the declining income and revenue generation from oil and gas in the year 2015. The highly unfortunate event forced the government to diversify and expand other sources such as agribusiness in order to help revitalize and boost the economy once again.

Agribusinesses term was put together by two Harvard professors Johan Davis and Ray Goldberg, in 1957. They define the concept as the entire operations involved in the production and distribution of farm supplies. It includes anything that has to do with enterprising agricultural output [3]. Agribusinesses are very significant in job creation and wealth creation. On the other hand, a value 
chain is a strategic relationship between an interdependent business that works towards adding value for the final consumers [1]. Agricultural value chains are designed to raise competitive advantage through collaboration that will link the producer, the marketer, the value-adding processors, transport, storage to the final consumer. Nigeria's agribusiness value chain consists of four categories [4], which include; pre-up-stream, up-stream, mid-stream, and down-stream.

The Nigerian agribusiness sector absorbs about $80 \%$ of the labor force [5]. According to [6], Nigeria's rural population is about $50 \%$ of the total population. It makes the livelihood of more than $195,874,740$ people directly or indirectly dependent on agriculture [7]. Despite the apparent contributions of agriculture to the country's economy, the agricultural sector in Nigeria is facing some challenges. The most prominent problems include climate change, degradation of natural resources, and population growth [8]. The Nigerian range of climate variations gives it an edge to be able to produce different kinds of crops ranging from food crops to cash crops [9].

Climate data records have shown how climate has been changing over the years with different indicators such as the global rise in temperature, rise in sea levels, melting ice glaciers, bush fires, hurricanes, and floods [10]. Climate change has a severe impact on human and natural systems, economic growth, and sustainability [10]. This paper aims to review the impact of climate change on the Nigerian agribusiness value chain. The paper also discussed climate change adaptation and mitigation strategies for a sustainable agribusiness value chain in Nigeria.

\section{Aims}

- The main aim of this paper is to review the impact of climate change on the Nigerian agribusiness value chain.

\section{Objectives}

- To understand the impact of climate change on Nigerian agribusiness value chain

- To understand how to adapt/mitigate climate change impacts on Nigerian agribusiness value chain

\section{Discussion}

Climate change is a long-term change in the average weather patterns that have come to define the earth's global climate [11]. It is evident that the climate has been changing for a very long time throughout the world's history [13]. The change in climate and temperature we see today are caused by factors such as human factors or natural factors [14]. A study conducted by [12] revealed that most of these changes in the global climate are associated with a little variation in the earth's orbit that changes the level of energy coming from the sun to the earth. There is a scientific consensus that climate change and global warming that occurred in the past century until now are caused by humans [12].

The climate is crucial to the Nigerian agribusiness value chain [15]. If action is not taken, the impact of the change on weather will continue to cause severe effects on livelihoods in Nigeria. According to [15], the temperature will continue to rise in the northern part of Nigeria, and also, the variability in rainfall will increase. The north will have less and erratic rainfall, which will lead to drought, whereas in the south, they will have more intense rainfall, which will result in floods.

Several studies have been conducted on climate change and its causes. Many studies revealed that the change in climate trends over the years is mostly caused by human activities [16]. According to [17], the human influence on the change in climate conditions is real, and the most common activity is the anthropogenic greenhouse gas emissions. [18] argued that the global climate is changing faster than at any time in the history of modern civilization because of human activities. Again, [19] explained that the climate change is real, and it will always be tough to understand a complicated system like the global climate. However, there is evidence in Nigerian agribusiness value chain that the climate is changing and global warming is happening.

According to [2], many sectors will suffer from the change in climate, but agriculture will face the deadliest. The author added, the agricultural industry is threatened by droughts, floods, land degradation, and soil salinity [2]. The arid northern part of Nigeria is facing severe heat and less rainfall [20]. The change in temperature in the region and precipitation patterns is affecting farming activities in Nigeria as well as damaging non drought tolerant or heat tolerant crops [20]. Experts in the field are already making conclusions on the issues of rising cases of crop failures and decrease in yields in Northern Nigeria is as a result of increase in temperature in the area [20]. A study conducted by [21] revealed that due to climate change, natural disasters are occurring more often than ever before. These disasters end up causing problems to the agricultural sector leading to financial losses. Climate change is increasing the rate of problems faced by Nigeria's agricultural sector [3].

A study by [22] revealed that climate plays a crucial role in agriculture. It has a direct impact on the productivity of physical production factors. The effects of climate change appear in every stage of food farming and its value chain. It affects planting, cultivation processing, storing, transporting to the consumer market. The change in climate also affects storage system. This is because increase in temperature increases pest infestation [20]. [4] argued that food production is highly dependent on the 
climate. The author also argued that, the impact of climate change is negative on the agricultural value chain [23]. The study also revealed that, despite the fact some regions will gain productivity from the change in climate, the agricultural sectors and human well-being will still be at a high risk. It will cause biological effects on crop yield, and it will affect the prices of food and cause hunger and malnutrition.

The continuous rise in global climate change has made agriculture the center of attention and the point of discussion worldwide. The agricultural sector is the most significant contributor to non-carbon dioxide greenhouse gas, which amounts to about $56 \%$ of the total greenhouse gas [5]. The total agricultural production, including direct and indirect emission, contributes to $80 \%-86 \%$ of the entire food system-emissions with very significant variances depending on region [24]. The underdeveloped countries are the most vulnerable when it comes to climate change impact on agricultural value chain [6]. This is mainly because the majority of the population in underdeveloped countries depend on agriculture [6]. Figure 1 below shows the global agricultural value chain greenhouse gas emission [25].

The impact of climate change on the agricultural value chain is expected to increase with time and by region [26]. Studies have shown how the change in climate affects the yield of agricultural production, the earnings from production, the quality of food, the storage $\&$ transport of produce, the food price, and also the food security [20] [23] [27]. According to [7], the continuous increase in global temperature and the increase in rainfall have a significant effect on the food production value chain. Again, given the prediction of early cessation of rainfall in northern Nigeria will cause short planting season which will result in food scarcity [28]. These changes in climate will bring about new problems. Critical issues that have the potential to affect natural resources, biodiversity, and the ecosystem, which could lead to changes in many elements, such as social, environmental, and economic status [23].

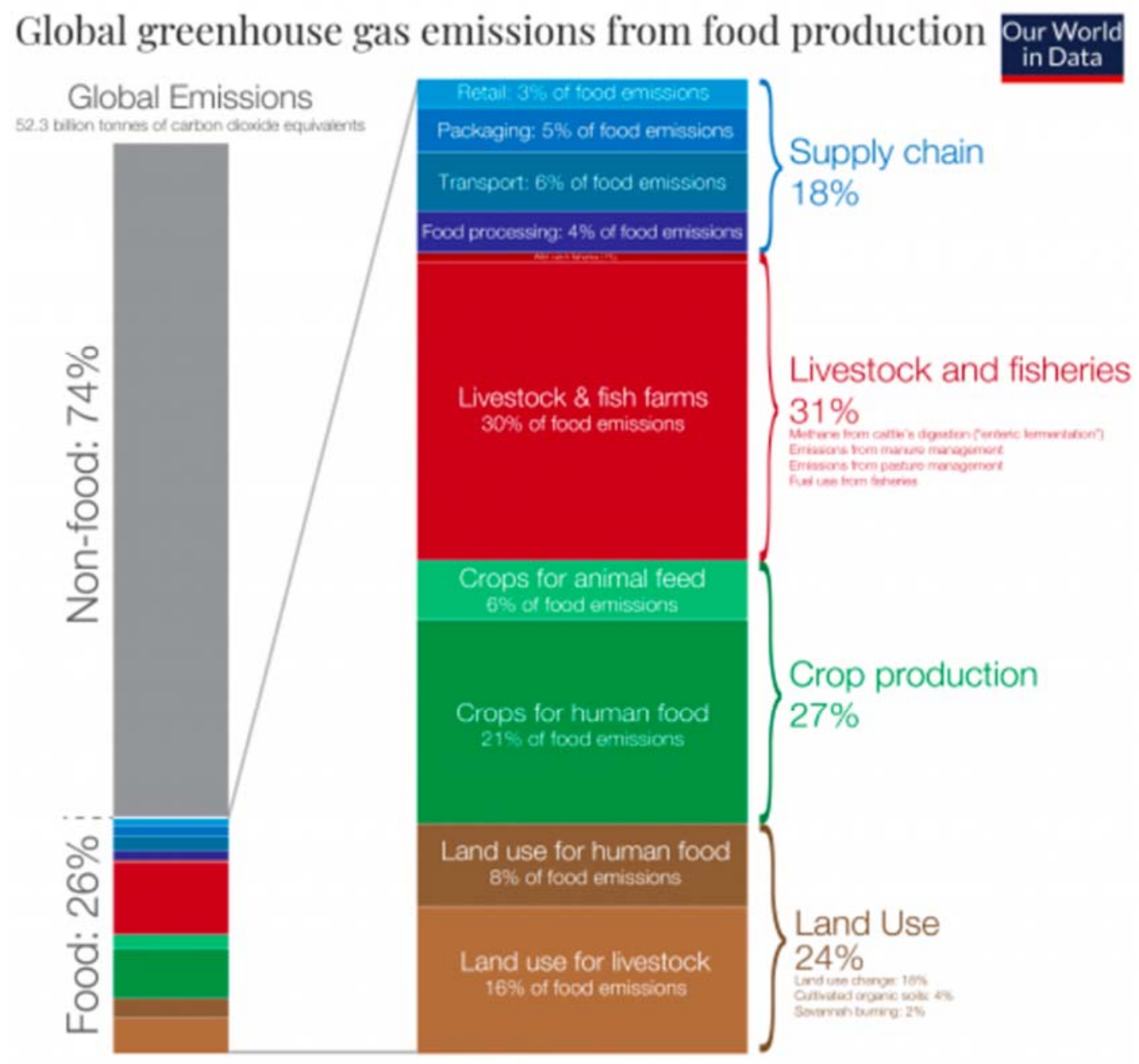

Figure 1. Global greenhouse gas emissions from food production [25] 


\section{About a third of all food produced is lost in the food supply chain}

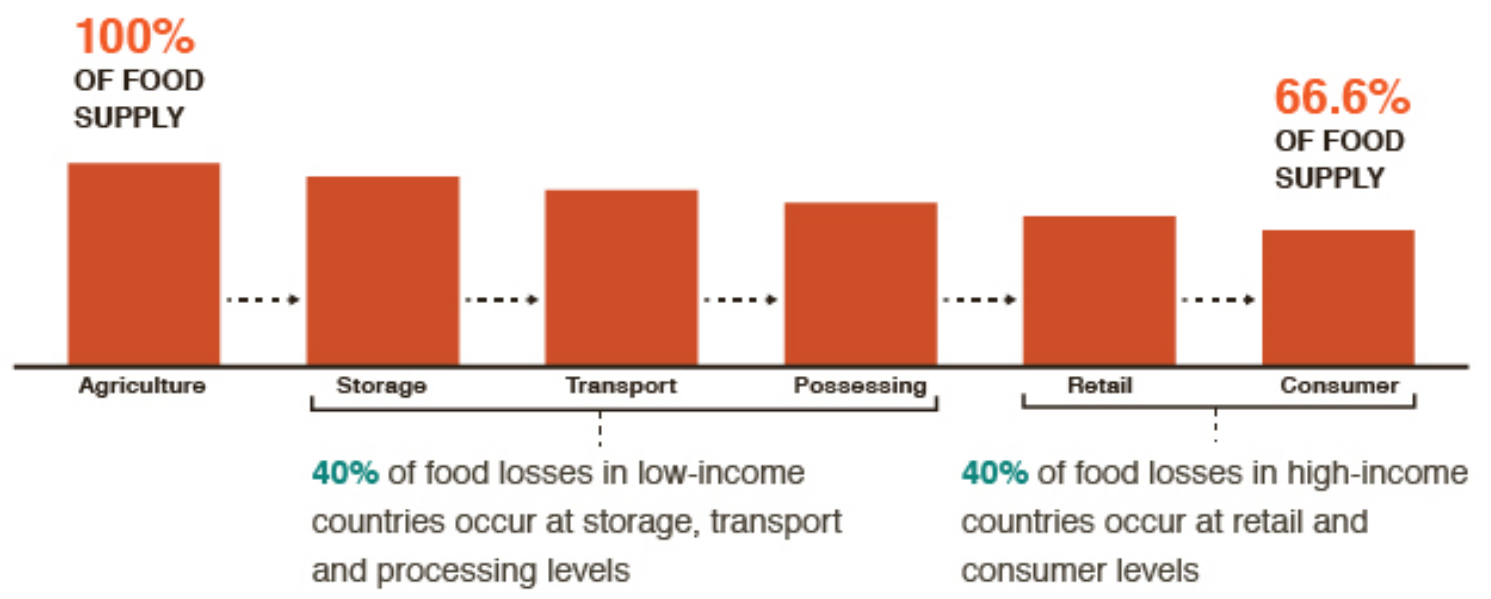

Figure 2. Global food loss on the supply chain (FAO, 2015)

The change in climate affects the different components of the value chain with different magnitude [26]. According to [29], climate change affects the agribusiness value chain in many ways. For example, figure 2 below shows how the food produced is being wasted along the value chain. Almost 40 percent of food is lost on the value chain before it reaches the final consumer as a result of different factors, which include the change in climate conditions. In low-income countries like Nigeria, food loss occurs at the very early stage between primary storage, transport, and processing. Whereas, in high-income countries, the loss occurs at the last stages of the value chain, such as retail and final consumer levels [29]. Figure 2 above shows how food is lost on the supply chain from production to the final consumer.

Based on the inexhaustible debates on the impact of climate change on the agricultural value chain in. Many empirical studies have been conducted by researchers to study the link between climate change and the agribusiness value chain. Evidence on the impact of climate change is not only on the production stage of the value chain, but it also occurs at different stages of the chain with varying intensity. The climate will affect many stages, such as; storage, secondary processing, transport, retail, and consumption [30]. [31] The northeast and northwest parts of Nigeria are the most vulnerable to climate change impact. Those regions are at a high risk because most of the food crop production is in those regions. The climate change challenges are not the same across the whole country, because of its tropical weather and two precipitation regimes: low precipitation in the south leads aridity, drought, and desertification in northern Nigeria [9]. Studies have shown Agricultural produce in Nigeria is mostly rainfed; the change in climate makes it hard to predict planting activities by farmers [32].

The fluctuation in climate patterns is exposing Nigeria's agricultural system to threats and therefore putting the value chain under serious stress. According to [10], in a study to find the effect of climate change on agricultural productivity in Nigeria. The study revealed that climate change has an impact on productivity. The increase in rainfall, rise in sea level, flooding, and soil erosion will affect the productivity of food production [8]. It also shows that the rise in temperature has a negative effect, while rainfall change exerts a positive impact on agricultural productivity. The study used descriptive and co-integration techniques to analyze the time series over a period of 14years. The study recommended that technologies be used to detect and reduce climate change impact on sustainability and better productivity.

The Nigerian agricultural value chain is a critical facilitator of economic growth to the country [11]. For the country to unlock the full potential of the system, the value chain has to be clearly understood. Understanding the value chain will enable the major actors to mitigate the climate change impact, such as land degradation, drought, weed, and pest [12]. The Nigerian agribusiness value chain is highly dependent on climate change. The fluctuation in climate patterns affects the food production value chain, the change in climate can disrupt food supply, it will affect the quality of food being produced, it will also affect the yield and increase exposure to weed and pest [33]. According to [8] direct impact of the climate chain on the agricultural value chain will appear on every step of the value chain but, the highest will be on farming. Farming is climate-sensitive and has the primary role to play in the food supply. The impacts of climate change on the food system are anticipated to be all over the world but will vary with location and with the socio-economic condition [29]. The smallholder farmers and low-income earners will be more exposed to the climate change threat. The adaptation and mitigation strategies, such as using renewable energy to reduce GHG emission and carbon footprint, will help reduce the impact and exposure [8].

According to [8] in a study shows how climate change 
is threatening agriculture and food production in Nigeria. The data of the study covers a period of 105 years, which was collected from FAO. The data revealed that there is a decrease in rainfall and an increase in temperature in the country. These changes are a result of the change in the climatic conditions of the region. Climate change is causing drought, land degradation, dessert encroachment, which is also affecting the agribusiness value chain in Nigeria. The study recommended good agricultural practices, and the adoption of agricultural technologies will reduce greenhouse gas emissions and bring sustainable development in the agricultural production value chain. According to [34], the small farmers are particularly the most vulnerable to climate change threats in the agribusiness value chain.

Again, the relative contribution of agribusiness to Nigeria's GDP has decreased. GDP From Agriculture in Nigeria has reduced to NGN3,677,153.49 in the first quarter of 2020, from NGN5,093,983.13 in the fourth quarter of 2019 [35]. Climate change affects different sectors of the economy, including agriculture and forestry, as the major sectors being impacted by climate change [17]. The agricultural sector is the largest known sector that is affected by climate change, because of size and the importance of the industry to the country [36]. Evidence from the pool of literature has shown the link between climate change and agribusiness. [4] studied climate change and sustainable food production. The study revealed one of the most significant challenges faced in the $21^{\text {st }}$ century is sustainability in agribusiness. To be able to feed 10 billion people by 2050 and reduce the impact of food production on the environment. Maintaining the status quo will not solve the current problem, but instead, strategic changes in the food production value chain will. Low agricultural productivity, soil erosion, low soil quality are problems that climate change is causing around the world [13]. The study evaluates potential ways to adapt or mitigate climate change impact. The study recommended management decisions that reduce soil erosion and increases carbon sequestration. They argued without reducing soil erosion and improving water conservation, and sustainability will be hard to achieve in the food value chain.

Climate change is increasing and becoming more threatening by the day because it affects both rural and urban development. The change in climate has caused the value chain a lot from low yield to loss of revenue. [34] recommended that all stakeholders in the value chain and the policymakers should include climate change mitigation strategies in short and long-term planning. [14] argued that climate change is indeed one of the serious and life-threatening environmental issues all over the world, and Nigeria is no exception. The rural population of the country produces more than $70 \%$ of the food consumed by Nigerians. And the rural population is the most vulnerable to climate change impact because of the farming activities carried out in those areas. [23] recommended the use of technology for smart agribusiness and food consumption-based measures to reduce greenhouse gas. The author also argued that looking at the magnitude of the problems of food security and reducing climate change impact, the country is not in a position to choose between increasing production and reducing climate change impact. The country needs to balance both increases in production to feed the ever-growing population and also minimize the effects of climate change from agricultural greenhouse gas emission [23]

The risk associated with the change in climate has the potential to cause a major loss in revenue for the agribusiness industry in Nigeria. However, [24] argued that the change in climate could also open new ways and new opportunities for some parts of the agribusiness value chain. Studies have shown many climate change effects on the Nigerian agribusiness value chain. The effect will vary with the location and components of the value chain [37]. This means that the result in northern Nigeria will be different from southern Nigeria. Also, the effect will hit each part of the value chain with varying magnitude. The impact on primary production might not be the same as the effect on the value-added activity stage. Again [38], in a study to understand the potential impact of climate change on Nigerian agriculture. It is revealed that the extreme temperature would have an economic impact that will cause a severe loss in value for most crops grown in the country, except for some crops grown in northern Nigeria, such as millet, melon, and sugarcane [38].

\section{Agribusiness Value Chain and Climate Change in Nigeria}

NIRSAL categorized the Nigerian agribusiness value chain into four main streams, mainly the pre-up-stream, upstream, midstream, and downstream [4]. NIRSAL is an acronym for Nigeria's incentive-based risk-sharing system for agricultural lending. It is a financial institution wholly owned by the central bank of Nigeria. The institution was created in 2013 in collaboration with the federal ministry of agriculture and rural development to fix agribusiness value chains and build long term capacity. The figure shows the different categories of business under each stream. 


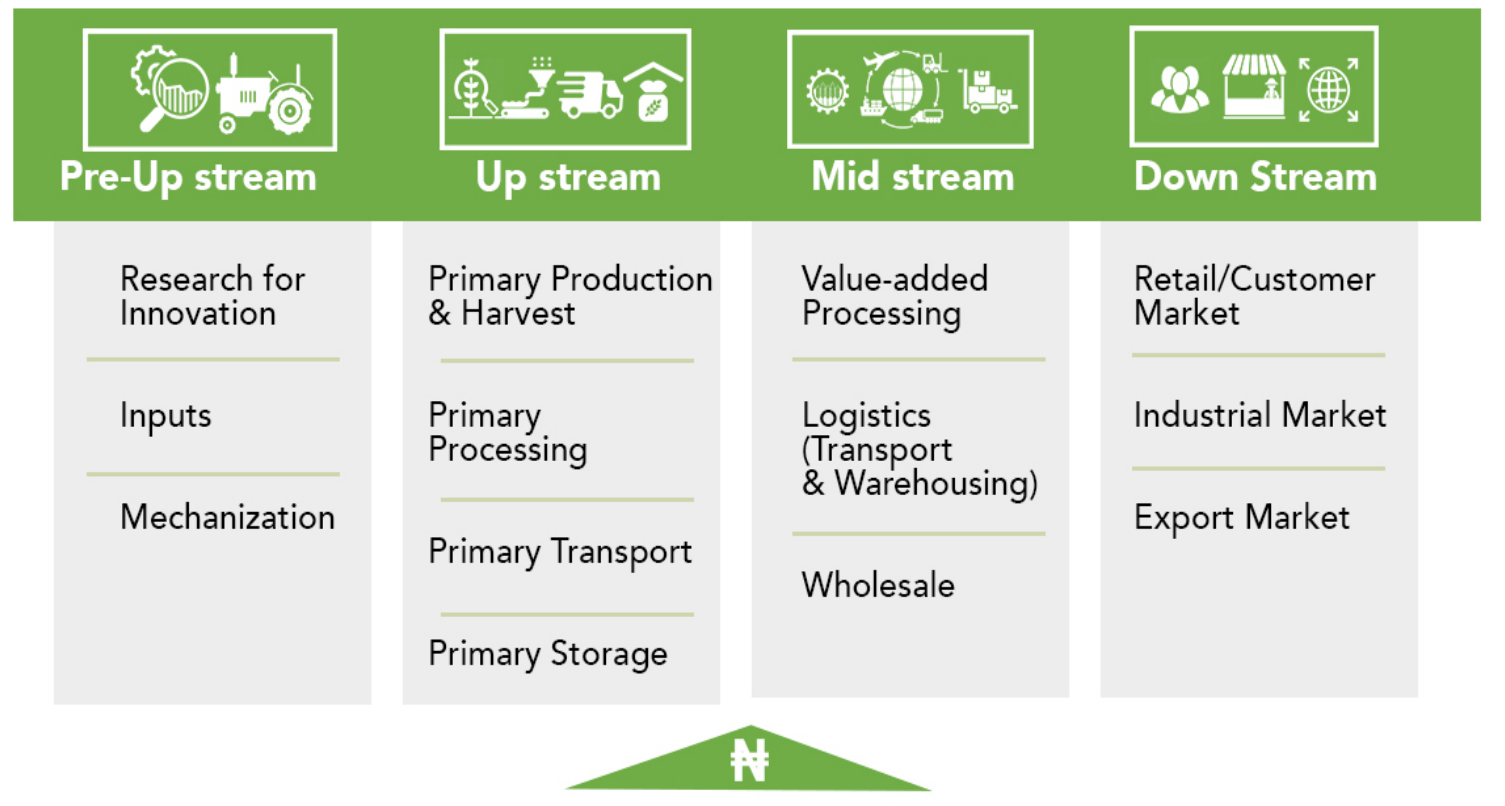

\section{Finance can only be attracted to fixed agricultural value chains}

Figure 3. Nigerian agribusiness value chain model [4]

Table 1. The Four Components of Nigerian Agribusiness Value Chain

\begin{tabular}{|c|c|}
\hline $\begin{array}{c}\text { Agribusiness Value chain } \\
\text { Component }\end{array}$ & Climate change impact \\
\hline Pre-upstream & $\begin{array}{l}\text { - According to [29] } 40 \text { percent of food produced in countries like Nigeria is wasted at the } \\
\text { pre-upstream and up-stream because of the climate and lack of technology, transportation, } \\
\text { infrastructure, and proper storage facilities. } \\
\text { The increase in temperature and variability in rainfall patterns have impact on the } \\
\text { pre-upstream aspect of the agribusiness value chain. According to [39], the majority of } \\
\text { Nigeria's food supply comes from the consumption of seed from grain crops such as rice, } \\
\text { wheat, millet, sorghum, cowpea, and maize. The grain crops are said to be the most } \\
\text { vulnerable to climate change impact. } \\
\text { The change in climate also influences the population and dimension of insects and pests [39]. } \\
\text { Change in climate can expose inputs to pests and diseases [20]. } \\
\text { The input supply has several parameters that depend on climate throughout the value chain } \\
\text { from primary production to harvest to processing and storage [40]. }\end{array}$ \\
\hline Upstream & $\begin{array}{l}\text { - Studies have been conducted that revealed the impact of climate change on agricultural } \\
\text { productivity leading to a decline in food production [20] [37]. } \\
\text { The increase in temperature events has the potential to increase the risk of produce spoilage } \\
\text { at this stage because of the poor storage facilities in the country and lack of technology [20] } \\
\text { [29]. } \\
\text { Climate change also affects the produce at the transportation stage because of poor roads and } \\
\text { infrastructure in Nigeria [29] } \\
\text { Climate change damage the crops, reduce yield and productivity because of pest infestation } \\
\text { increase as a result of increase in temperature [20] [41] } \\
\text { Change in climate causes drought and flood which can lead to a loss in revenue, hunger and } \\
\text { also affects global food security [42] } \\
\text { Change in climate increase the need for the use of more pesticides and fertilizers. The } \\
\text { fertilizer have impact on the soil, and the pesticides can leave residue on produce which is } \\
\text { harmful to humans [43] }\end{array}$ \\
\hline Midstream & $\begin{array}{l}\text { - An increase in temperature causes food wastage and contamination before value-adding } \\
\text { processing in most underdeveloped countries like Nigeria. This is because of the lack of } \\
\text { power supply, proper storage facilities and bad roads [29] } \\
\text { Extreme weather conditions may disrupt operations at this stage such as power supply and } \\
\text { labor [44] }\end{array}$ \\
\hline Down-stream & $\begin{array}{l}\text { - Climate change such as flood can disrupt distribution to industrial markets or export markets } \\
\text { because of poor infrastructure [45] } \\
\text { - Increase in temperature can increase the risk of pathogens that can contaminate produce [46] }\end{array}$ \\
\hline
\end{tabular}




\section{Adaptation and Mitigation Strategies}

Several studies recommended the use of good agricultural practices such as precision farming in agriculture, the use of climate-smart technologies to reduce greenhouse gas emissions from agriculture while increasing productivity. According to [14], using a renewable source of energy is one way to fight the ever-growing impact of climate change on agribusiness. Again [47] suggested the use of precision farming techniques to increase productivity in the agribusiness value chain. Using precision farming can reduce climate change impact while ensuring sustainable use of water supply, agrochemicals, and energy usage. The use of low till farming, precision agriculture, soil fertility management systems, drip and sprinkler irrigation, drought and heat tolerant seeds and crop protection is highly recommended in trying to reduce greenhouse emission from agriculture [47].

\section{Conclusion}

In conclusion, it is evident that the change in climate conditions and pattern have a severe impact on the Nigerian agricultural value chain. Evidence from existing literature shows that climate change results in food access disruption, land degradation, flood, drought, reduce food quality, chances of weed and pest, and low yield. It is therefore recommended that value chain actors become more enlightened about strategies to mitigate climate change impacts. It is also crucial for stakeholders to change from traditional practice and accept new climate-smart technologies in various categories of the value chain. Good practices in the value chain can bring about sustainable development of the industry and economic growth of the country. Researchers have argued that human activities are the primary cause of global warming. Crops are victims of climate change impact; this is caused by drought in regions where temperatures are already high. Therefore, the renewable source of energy is recommended to reduce the effect on humans and the environment.

\section{REFERENCES}

[1] FAO, "Nigeria at a glance, " 2020.

[2] OECD and FAO, Agricultural Outlook 2019-2028. 2019.

[3] J. H. Davis, "A Concept of agribusiness," no. February, pp. 1042-1045, 2018.

[4] NIRSAL, "Our expertise-Value chain fixing," 2020. [Online]. Available: https://nirsal.com/our-expertise/\#!/value-chain. [Accessed: 29-Apr-2020].
[5] K. Sertoğlu, S. Ugural, and F. V. Bekun, "The Contribution of Agricultural Sector on Economic Growth of Nigeria, " Int. J. Econ. Financ. Issues, vol. 7, no. 1, pp. 547-552, 2017.

[6] The world bank and World Bank, "The world bank in malaysia," The World Bank Research Observer, 2020. [Online]. Available: https://www.worldbank.org/en/country/malaysia/overview. [Accessed: 02-Jul-2020].

[7] World Bank, "The World Bank In Nigeria," The World Bank Research Observer, 2019. .

[8] B. O. B. et al., "Evidence of Climate Change Impacts on Agriculture and Food Security in Nigeria, " Int. J. Agric. For., vol. 2, no. 2, pp. 49-55, 2012, doi: 10.5923/j.ijaf.20120202.08.

[9] S. Fakayode, M. A. Y. RAHJI, and S. Adeniyi, "Economic Analysis of Risks in Fruit and Vegetable, " Bangladesh $J$. Agril. Res, vol. 37, no. September, pp. 473-491, 2012.

[10] A. Balasubramanian, "Indicators of Global Climate Change, " no. March, 2017, doi: 10.13140/RG.2.2.11485.41444.

[11]H. Shaftel, "Climate Change: Vital Signs of the Planet: Causes," Nasa. 2016.

[12] S. Pappas, "What is climate change, and how is it affecting Earth?, " NASA, 2020. [Online]. Available: https://www.livescience.com/climate-change.html. [Accessed: 30-Apr-2020].

[13] C. S. L. Dias et al., "A Status Quo Review of Climate Change and the Agriculture Sector of the Western Cape Province, " Ecosyst. Serv., 2016, doi: 10.1017/CBO9781107415324.004.

[14] Umair Shahzad, "Global Warming: Causes, Effects and Solutions," no. May, 2017, doi: https://www.academia.edu/15180958/Global_Warming_C auses_Effects_and_Solutions.

[15] H. Posthumus, J. Dengerink, M. Dhamankar, C. Plaisier, and G. Baltissen, "Enhancing Food Systems in Nigeria;Scope and perspective for Dutch policy interventions," Netherlands Minist. Foreign Aff., 2019.

[16] Y. T. Sodangi I. A., Izge, A. U., Maina, "Climate Change: Causes and Effects on African Agriculture, " J. Environ. Issues Agric. Dev. Ctries., vol. 3, no. 3, pp. 22-33, 2011.

[17] Intergovernmental Panel on Climate Change, Climate Change 2014 Mitigation of Climate Change. 2014.

[18] NASA, "Scientific Consensus: Earth's Climate is Warming, " NASA, 2020.

[19] IPCC, "The carbon cycle and atmospheric carbon dioxide," in Climate Change 2001: The Scientific Basis, 2001.

[20] O. C. Chukwuezie, N. Nwakuba, K. N. Nwaigwe, and S. Asoegwu, "The impact of climte chnage on Nigerian agricultural sector and economy, "Agric. Bioresour. Eng. Gatew. to Divers. Niger. oil-based Econ. job wealth Creat. Environ. Sustain., no. October 2017, pp. 498-507, 2016.

[21] P. X. Pham and D. N. Nguyen, "Study on assessment of indigenous knowledge in adapting to floods of farmers in An Giang province," Sci. Technol. Dev. J. - Sci. Earth 
Environ., 2019, doi: 10.32508/stdjsee.v2i2.495.

[22] C. S. Mesike and T. U. Esekhade, "Rainfall variability and rubber production in Nigeria, " African J. Environ. Sci. Technol., vol. 8, no. 1, pp. 54-57, 2014, doi: 10.5897/ajest2013.1593.

[23] P. Smith and P. J. Gregory, "Conference on 'Future food and health' Symposium I: Sustainability and food security Climate change and sustainable food production Proceedings of the Nutrition Society, " no. November 2012, pp. 21-28, 2013, doi: 10.1017/S0029665112002832.

[24] S. Vermeulen, "How to do Climate change risk assessments in value chain projects," IFAD Environ. Clim. Chang. Clim. Chang., p. 24, 2015.

[25] J. Poore and T. Nemecek, "Reducing food's environmental impacts through producers and consumers, "Science (80-. )., vol. 360, no. 6392, pp. 987-992, 2018, doi: 10.1126/science.aaq0216.

[26] S. J. Vermeulen, B. M. Campbell, and J. S. I. Ingram, "Climate Change and Food Systems, " Annu. Rev. Environ. Resour., vol. 37, no. 1, pp. 195-222, 2012, doi: 10.1146/annurev-environ-020411-130608.

[27] C. Siwar, M. Alam, W. Murad, and A. Q. Al-, "Impacts of Climate Change on Agricultural Sustainability and Poverty in Malaysia," pp. 1-15.

[28] K. Akomolafe, O. Awoyemi, and A. Babatunde, "Climate Change and Its Effects on Agricultural Outputs in Nigeria," Asian J. Agric. Extension, Econ. Sociol., vol. 25, no. 2, pp. 1-11, 2018, doi: 10.9734/ajaees/2018/37136.

[29] FAO, "Food wastage footprint \& Climate Change, " Food wastage Footpr. Clim. Chang., no. 1, pp. 1-4, 2015.

[30] A. Abdulkadir, A. Maryam Lawal, and T. I. Muhammad, "Climate change and its implications on human existence in Nigeria: a review," Bayero J. Pure Appl. Sci., vol. 10, no. 2, p. 152, 2018, doi: 10.4314/bajopas.v10i2.26.

[31] J. E. Ogbuabor and E. I. Egwuchukwu, "The impact of climate change on the Nigerian economy," Int. J. Energy Econ. Policy, 2017.

[32] B. Anabaraonye, J. C. Okafor, and J. Hope, "Educating Farmers in Rural Areas on Climate Change Adaptation for Sustainability in Nigeria, " Handb. Clim. Chang. Resil., vol. 10, no. 4, pp. 2771-2789, 2020, doi: 10.1007/978-3-319-93336-8_184.

[33] C. Flavelle, "Climate change threatens the world's food supply, United Nations warns, " The New York Times, 08-Aug-2019.

[34] Veronica Makuraro, "Veronica Makuraro, 2014, Impact of climate change on smallholder farming zimbabwe.pdf. " University of the free Ftate, South Africa, 2014.
[35] Trading Economics, "Nigeria GDP From Agriculture 2010-2017 Data Chart Calendar," 2020. [Online]. Available: https://tradingeconomics.com/nigeria/gdp-from-agriculture. [Accessed: 19-Aug-2020].

[36] S. N. Seo, R. Mendelsohn, A. Dinar, R. Hassan, and P. Kurukulasuriya, "A ricardian analysis of the distribution of climate change impacts on agriculture across agro-ecological zones in Africa," Environ. Resour. Econ., 2009, doi: 10.1007/s10640-009-9270-z.

[37] Rabekka and Berry, "The Climate Change, Food Security and Human Health Nexus in Canada: A Framework to Protect Population Health.pdf," Int. J. Environ. Res. Public Health, 2019, doi: doi:10.3390/ijerph16142531.

[38] O. Ajakaiye, J. Ajetomobi, and A. Gbadegesin, "The Potential Impact of Climate Change on Nigerian Agriculture," no. October, 2013.

[39] R. P. Singh, P. V. V. Prasad, and K. R. Reddy, Impacts of Changing Climate and Climate Variability on Seed Production and Seed Industry, vol. 118. Elsevier, 2013.

[40] A. Maity, D. Vijay, A. Mukherjee, and A. Lamichaney, "Potential impacts of climate change on quality seed production: A perspective of hill agriculture," in Conservation Agriculture: An Approach to Combat Climate Change in Indian Himalaya, 2016.

[41] C. Zhao et al., "Temperature increase reduces global yields of major crops in four independent estimates, " Proc. Natl. Acad. Sci. U. S. A., vol. 114, no. 35, pp. 9326-9331, 2017, doi: $10.1073 /$ pnas. 1701762114 .

[42] S. B. Akpan, U. E. Okon, U. J. Udo, and A. Campus, "Influence of climate change indicators on agribusiness growth index in nigeria," pp. 658-666, 2017.

[43] J. Ziemacki, D. Callo-Concha, and M. Thiel, "The residual effect of fertilizer in soil: Can crop rotation practices combat soil fertility loss and increase crop yield?, " 2018, doi: 10.17011/conference/eccb2018/107779.

[44] M. Panteli and P. Mancarella, "Influence of extreme weather and climate change on the resilience of power systems: Impacts and possible mitigation strategies, " Electric Power Systems Research. 2015, doi: 10.1016/j.epsr.2015.06.012.

[45] R. Dellink, H. Hwang, E. Lanzi, and J. Chateau, "International trade consequences of climate change," OECD Trade Environ. Work. Pap., vol. 01, 2017, doi: 10.1787/9f446180-en.

[46] B. Smith and A. Fazil, "How will climate change impact microbial foodborne disease in Canada?, " Canada Commun. Dis. Rep., 2019, doi: 10.14745/ccdr.v45i04a05.

[47]IFC, "Precision Farming Enables Climate-Smart Agribusiness," pp. 1-5, 2017. 